\title{
Impact of Customer-to-Customer Interaction (CCI) on Customer's Purchase Behavior in E-Commerce
}

\author{
Ruoqian Yang \\ Business School of XinYang University \\ China, 464000
}

\begin{abstract}
With the development of e-commerce, e-commerce logistics service industry as a new service industry has become the focus of development to enhance the overall level of China's e-commerce service network system. E-commerce logistics service providers in convenience and improve the efficiency of service at the same time, reduce the interaction between customer and enterprise employees, and make the customer interaction become a customer service success rate and an important factor to improve the purchase intention of customer service. Therefore, it has important research value to study the impact of customer interaction in virtual service environment on the purchase intention of service. According to the characteristics of ecommerce logistics services, customer interaction focus on the logistics network of service process, discussed in the this virtual network service environment, the relationship between purchase intention of customer interaction and service.
\end{abstract}

Keywords-Customer interaction; Perceived risk; Perceived value; Service purchase intention; E-commerce service

\section{INTRODUCTION AND BACKGROUND}

At the end of the 20th century, the Internet causes the change of "the Information Scarcity Age" to "the Information Democracy Age". With the advent of the era of information technology and the optimization of the logistics industry, Internet users have increased dramatically in China. "China's netizen population, the world's largest, continues to grow and reached 591 million at the end of June, 2013, the country's network information center said. Out of all the netizens, 78.5 percent of 464 million use mobile phones to access the internet, up 4 percentage points compared with the end of 2012, according to a report issued by China Internet Network information Center (CNNIC)". (http://www.chinadaily.com.cn, 2013) $)^{[1]}$

Global electronic commerce development is growing exponentially. "The CNNIC report said the country's mobile phone netizens have developed a heavy reliance on their devices as they each spent an average of 11.8 hours per week to go online. This also helped trigger an increase in mobile phone-related e-commerce, including online shopping, payment and banking, which grew 3.3 percent, 3.9 percent and 2.7 percent respectively compared with the end of last year. "(http://www.chinadaily.com.cn, 2013) $)^{[2]}$

The transaction value for China's e-commerce industry in the first half of 2010 was $\$ 332.6$ billion, of which 91 percent consisted of the business-to-business sector with the remainder made up of the business-to-consumer and consumer-toconsumer sectors, according to China e-Business Research Center (http://www.chinadaily.com.cn, 2010). Consumers in the Asia-Pacific region have spent more on e-commerce purchases in 2014 than consumers in North America, making them the largest regional e-commerce market in the world (JenHer Wu, Qi Li, Kwok Kee Wei, 2016). According to the data from Emarketer, a consulting firm, in 2015, the e-commerce spending in China accounts for $15.9 \%$ of total retail sales (Fig. 1). (http://tech.ifeng.com)

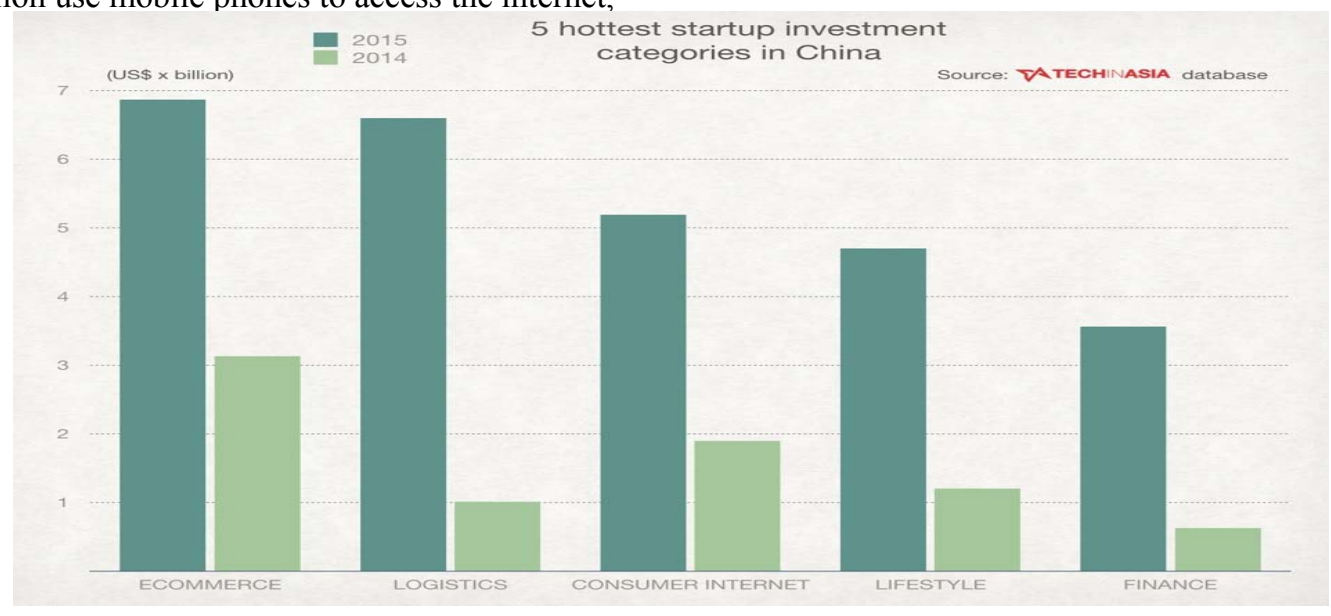

Fig. 1. 5 Hottest Startup Investment Categories in China (2015) 
The sound development momentum of electrical commerce (e-commerce, for short) is changing all aspects of social and economic life. Online shopping has become one of the main channels of consumption. ${ }^{[3]}$ The number of customers shopping on the Internet presents an upward tendency in a straight line. E-commerce integrates with the traditional industry in a great speed and turns out to be an important growth point of China' s economy. According to the data from Statistical Company the estimated per capita consumption expenditure of online shopping spending in China will reach 626 dollars (Fig. 2). (http://fm.m4.cn)

\section{Online shopping spending around the world}

Estimated average e-comerce revenue per online shopper in 2015

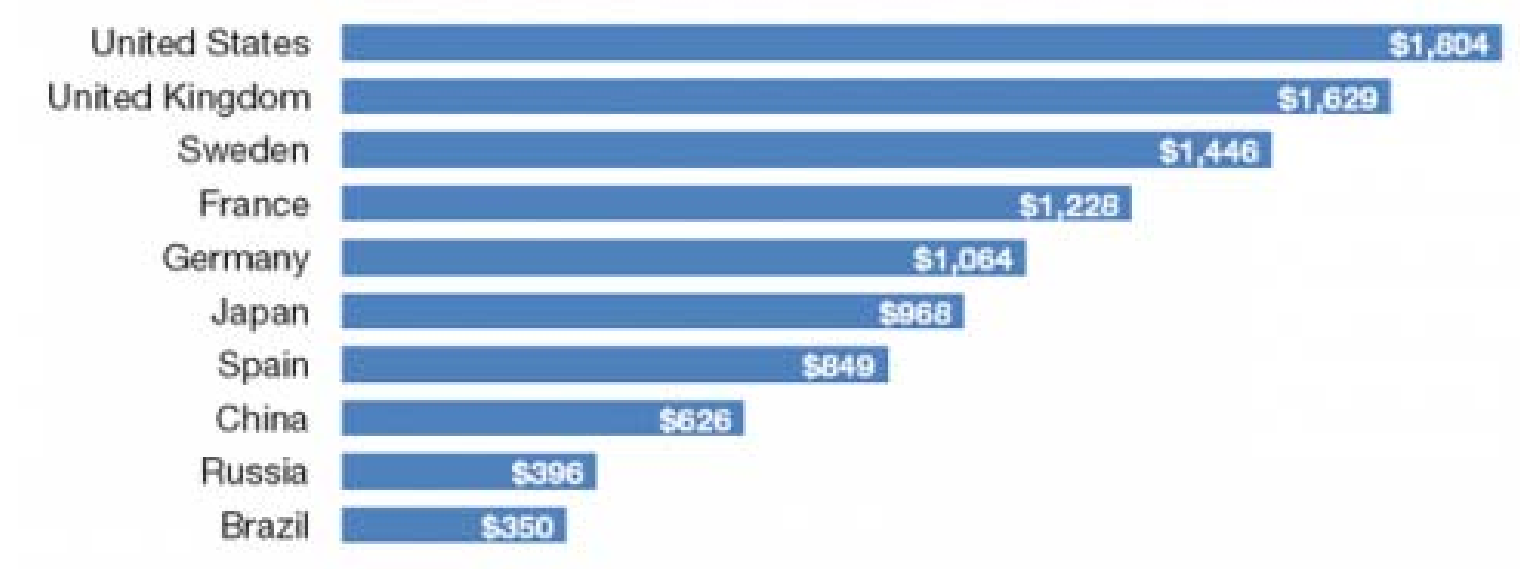

Source: Statista Digital Markot Outlook

Fig. 2. Online Shopping Spending around the World (2015)

Thus the power of the traditional business has gradually weakened. It is difficult for enterprises to establish sustainable competitive advantages in the market. They also find it difficult to cultivate and maintain customers' loyalty, which is the key for an enterprise to gain benefit. ${ }^{[4]}$

While there are no doubts about the vast potential of ecommerce, it is its ability to reach out to customers in remote areas of China, where stores are few and the costs of building a physical retail presence high that is proving irresistible to Western companies. ${ }^{[5]}$ However, because of the limitation of network shopping, customers can't have direct contact with products, which leads to the uncertainty of the purchase. "Despite the prospects is optimistic, a shortage in types of online payment, lagging logistic and lack of relevant laws are just some of the problems which continue to hinder the development of online shopping. ${ }^{,[6]}$ (http://www.docin.com) "Online shopping has and services garnered nearly 11,400 individual consumer complaints in Shanghai last year, up 18 percent from the previous year, with truth in advertising and the quality of products triggering the most consumer grievances." (http://usa.chinadaily.com.cn) And the strengths and weaknesses of online-shopping are analyzed by some researchers in China. For example, the following table which was given by CNNIC in 2009 gives a statistics of factors of consumers dissatisfied with online-shopping (Figure 2). (Li Milong, 2010) From which we may find out that customers will not be satisfied with online shopping for all kinds of factors. ${ }^{[7]}$
TABLE I. STATISTICS OF FACTORS OF CONSUMERS DISSATISFIED WITH ONLINE-SHOPPING (2010)

\begin{tabular}{|c|c|}
\hline Factors & Proportion \\
\hline Goods does not match the pictures & $52.3 \%$ \\
\hline Merchandise is fake & $25.0 \%$ \\
\hline Shoddy or damaged goods & $22.7 \%$ \\
\hline Too long time of delivery & $21.2 \%$ \\
\hline Bad attitude of courier & $15.7 \%$ \\
\hline Goods damaged during shipping & $11.3 \%$ \\
\hline Shipping costs are too high & $10.8 \%$ \\
\hline
\end{tabular}

Trying to avoid the disadvantages of online shopping, the customers will compare products and services of different enterprises on the Internet, spending only a little time and energy. ${ }^{[8]}$ They are free to read all kinds of information published by other customers on the Internet, communicating with them easily.

In this situation, customer-to-customer interaction (short as CCI) turns out to be a most important element which will directly affect customers' behavior on the internet. "Value creation through customer-to-customer exchange occurs when the perceived benefits of a company's offering are increased as a result of customers' interaction with one another." (Thomas W. Gruen, Talai Osmonbekov, Andrew J. Czaplewski, 2007) And customer-to-customer interaction turns out to be an extremely important factor of developing customers' shopping experiences and customers' loyalty. ${ }^{[9]}$ 


\section{IMPORTANCE OF THE RESEARCH}

\section{A. Importance of Customer-to-customer Interaction}

In the e-commerce, what we often mentioned as "marketing word-of-mouth effect" in the traditional environment, will be further enlarged under the environment of e-commerce. "Though word-of-mouth (w-o-m) communications is a pervasive and intriguing phenomenon, little is known on its underlying process of personal communications. Moreover as marketers are getting more interested in harnessing the power of $\mathrm{w}-\mathrm{O}-\mathrm{m}$, for e-business and other net related activities, the effects of the different communications types on macro level marketing is becoming critical. " (Jacob Goldenberg, Barak Libai \& Eitan Muller, 2001) "Increasingly, consumers use the internet as a vehicle for pre-purchase information gathering. While technical specifications and potentially biased selling points can be gleaned from corporate web sites, online brand communities are becoming essential conduits for the customerto-customer sharing of product information and experiences." (Mavis T. Adjei, Stephanie M. Noble \& Charles H. Noble, 2010)

Customers can recommend their favorite products in all kinds of ways, for example, web sites, emails, BBS, bulletin boards, or even virtual community.[10]The customers are accustomed to browsing the network platform for more information of the products and the users' experience and comments on message boards before they make purchase decisions. At the same time, after customers have bought products on the website, they are also used to making their comments and remarks on the Internet. Online reviews have got the features of wide range, high speed, containing large amount of information, anonymity and scalability, storable, etc. As Katona (1978) noted that the use of consumer attitudes for forecasting is based on the assumption that 'attitudes and expectations intervene between stimuli and response and they change before behavior changes'. (Adamu Ibrahim, Sani Bawa, Ismaila S. Abdullahi, Chizoba E. Didigu \& Sani S. Mainasara, 2015)

Thus, the customer-to-customer interaction, which is traditionally used to denote interactions between customers during the service encounter, becomes an important factor in ecommerce. ${ }^{[11]}$ No matter where the CCI happens, through customers' physical presence on-site or through their virtual presence on the Internet, it can promote interaction between customers, avoiding customers' perceived risk and promoting customers' purchase intention. It can also affect customers' emotion and their evaluation of the quality of the products and service. ${ }^{[12]}$

The huge market and infinite business opportunities contained in the E-commerce make it the most dynamic economic growth point in the world, and at the same time, a double-edged sword for the enterprises, providing not only rapid development and opportunities, but also unprecedented challenges. Therefore, the CCI in e-commerce plays an important role in Customers' satisfaction and loyalty. That's why CCI becomes one of the most important factors in the innovative e-commerce and attracts a lot of attentions of researchers all over the world. ${ }^{[13]}$

\section{B. Importance of Customer Experience}

According to Esteban Kolsky, who has over 20 years' experience in customer strategy and Customer Relationship Management solutions, and was named by CRM Magazine as an Influential Leader for 2011, customer experience is defined as the sum total of conscious events, as a coordinated series of interactions between a customer and a brand to accomplish anything. (Vala Afshar) Above all words - a customer experience is defined by the customer, for the customer, at each touch-point, each time (http://www.huffingtonpost.com).

In commerce, customer experience is the product of an interaction between an organization and a customer over the duration of their relationship. This interaction includes a customer's attraction, awareness, discovery, cultivation, advocacy and purchase and use of a service. It is measured by the individual's experience during all points of contact against the individual's expectations. ${ }^{[14]}$

In some researches, people investigated agreed that they'd trust a review by someone they knew over that of a critic. Online exchanges often occur between strangers who cannot rely on past behavior or the prospect of future interactions to establish mutual trust (Jalal Eddine Bahbouhi, Najem Moussa, 2017). So a positive experience for one customer may not only bring repeat business from themselves but from people that they know and recommend you to as well.

\section{Importance of Customer Loyalty}

If a customer likes you and continues to like you, they will do business with you. If they don't, they won't. Paul Greenberg defines customer engagement as "the ongoing interactions between company and customer, offered by the company, chosen by the customer." (Anum Hussain, 2014). The importance of customer loyalty has been recognized in marketing literature for at least three decades. The development and empirical validation of a customer loyalty in e-commerce is even more important. ${ }^{[15]}$

Customer loyalty is seriously powerful and valuable in business, no matter in traditional business or in e-commerce. According to the researches, retained and repeat customers will cost less than acquisition of a new customer. Nurturing loyal customers is a vital part of any retail marketing plan. Once the customer is satisfied with the service your business supplied, he/she is more likely to spread your name through word-ofmouth. In that way, customer loyalty is really worth keeping. ${ }^{[16]}$

It requires participation and hard work by the entire organization, and it is an ongoing mission with no end. But on the way you collect an immeasurable benefit - a loyal customer. We recommend that online retailers promote website identification to attract and retain repeat customers by focusing on the attractiveness of the website and product offerings while maintaining a high degree of trust. (Ruth C. King, Richard A.M. Schilhavy, Charles Chowa, Wynne W. Chin, 2016) 


\section{RELATED INFORMATION ABOUT THE RESEARCH}

\section{A. Gap in Academic Literature}

Literature review: In 2000, Erik Brynjolfsson, an American academic, puts forward the idea the Internet reduces the economic friction. (Joseph P. Bailey, 1998) Because of the low cost of the Internet transaction, customers can choose among the competitive suppliers. This provides the e-commerce with the basic characteristics of "perfectly competitive market", the competitive price and the small profits. Enterprises are no longer masters of the market. ${ }^{[17]}$

According to Harris and Baron (2000), the 'opportunity to mix with other people' is a central aspect of the customer experience when purchasing goods. Aubert-Gamet and Cova (1999) call the service escape an extension of home for the purpose of contact with the public and social exchange. Research shows that social interaction among customers has been effective in increased customer loyalty. (Rakesh Sapna, Khare Arpita; 2008) Technology enables fast and economical communication among customers independent of their geographical residence.

Gap in the researches:

Wide researches of customer-to-customer interaction (CCI) have been done by scholars and researchers home and abroad, which will be listed by the author in the part of Literature Review later.

Some researchers are about CCI in traditional business; some are about the characteristics in electrical commerce and others are about the importance of CCI having on customer experience or customer loyalty, etc.

There are few empirical studies be done to explore the relationship among all of these elements in electrical commerce, especially in China. "Although the importance of customer orientation has been well addressed in strategic marketing, these ideas generally focus on managing business-to-customer interactions. Strategic importance of understanding customerto-customer interactions has received very little attention." (Kaleel Rahman, Ingo O. Karpen, Mike Reid \& Ulku Yuksel, 2015) "Few empirical studies have been conducted to explore how customer-to-customer interactions affect satisfaction, loyalty." (Meysam Fakharyan, Sadaf Omidvar, Mohammad Reza Khodadadian, Mohammad Reza Jalilvand \& Leila Nasrolahi Vosta, 2014)

Therefore, the problem of how to make good use of CCI in E-commerce to promote the customers on purchasing is really worth studying. The purpose of this paper is to address this knowledge gap.

Research Question: In this study, based on the analysis of characteristics of China's e-commerce web services environment in 2015, reviews the relevant literature of CCI, the author aims to investigate the impact of CCI on customer's purchase behavior in E-commerce, to prove that customer-tocustomer interaction will have great influence on service purchase behavior intention, which plays a moderating role in customer experience.

\section{B. Research Problems and Proposition}

The study will have both practical implications and social implications. For enterprises' owners and researchers, a variety of perspectives on how CCI can influence the customers' purchase behavior are provided. Meanwhile, the article contributes towards developing a scientific approach towards understanding a phenomenon which is a widespread feature of social life.

First of all, customers' online review will be analyzed. Basically, the online review will be divided into two basic types: one type is subjective, emotional and the other type is clear and specific, and even with users' arguments supported to their point of view.

Secondly, the main formats of customers' online review will be analyzed. The online review is divided into two kinds, one kind is formatted review and the other kind is descriptive review. Actually, as formatted review fails to present the details, its quality of evaluation is not as good as the descriptive review.

Thirdly, the following three detail questions will be researched:

1. Will the content of customers' online review have a positive influence on other customers and promote their purchase intention?

2. Will the attitudes of customers' online review have a positive influence on other customers and promote their purchase intention?

3. Will the quantity of customers' online review have a positive influence on other customers and promote their purchase intention?

\section{Justification for the Research}

As we know, profits are the key for enterprises to survive. In recent years, the importance of CCI in E-commerce gets more and more attention from scholars and has caused scholars' wide attention and researches. For example, Jin Ho Jung and Jay Jaewon Yoo had attempted to examine 'how both positive and negative customer-to-customer interactions simultaneously influence customer citizenship behavior'. (Jin Ho Jung, Jay Jaewon Yoo, 2016)

This study examines how both positive and negative customer-to-customer interactions simultaneously influence customer citizenship behavior. Researchers have noted that it is imperative to take a closer look at the impact of CCI on customer's purchase behavior in E-commerce, which is an important factor to boost customer service and increase customers' willingness to buy the products on purchase intention. ${ }^{[18]}$

This paper selects experiences of customers with online shopping as the research objects, selects customers' online review as an intervening variable, with other two important related independent variables, customers' perceived risk and customers' purchase intention. Furthermore, how these independent variables will impact the customer's purchase behavior in E-commerce will be studied. On this basis, the 
theory model framework will be founded about the impact of CCI on customers' purchase intention in E-commerce.

In this theory model framework, the quality of the content of the customers' online review, the potency of the customers' online review, the quantity of the customers' online review will all be included as important factors affecting customers' purchase intention. The questionnaire survey will be adopted for collecting data and the statistical software SPSS will be applied for data analysis. ${ }^{[19]}$

\section{MANAGERIAL IMPLICATIONS}

Greenberg recently defined customer engagement as: 'The ongoing interactions between company and customer, offered by the company chosen by the customer.' Although this definition is specific to customer engagement, which is different from customer experience, the main point of emphasis is similar - offered by the company, chosen by the customer.

Because of the internet, we are living in an 'always-on' world. "With the growth of new information and communications technologies, each human relationship is becoming a continual presence. You can exchange a dozen brief cell phone conversations with your spouse every day. You can keep track of your money through on-line banking. Your computer-mediated work activities can always be visible to your co-workers. This is a tremendous shift in human relationships: from episodic to always-on. "( Agre P.E, 2001)

In this world, customer engagement is no longer a series of one-off experiences. Instead, it turns into an ongoing process because it will happen anywhere and anytime. As a result, the relationship between the company and the customer is more equal than ever, which forces the companies to formulate their communications with the customers.

That's why our research about 'whether the customer-tocustomer interaction will have meaningful effect on customers' service purchase behavior intention' is necessary and important. This research question will be further explored through three specific aspects:

1. Will the content of customers' online review have a positive influence on other customers and promote their purchase intention?

2. Will the attitudes of customers' online review have a positive influence on other customers and promote their purchase intention?

3. Will the quantity of customers' online review have a positive influence on other customers and promote their purchase intention?

\section{CONCLUSION}

With the increasing globalization, business takes place electronically generally over the Internet. E-commerce turns out to be a global trend. And there are more and more demanding customers, which mean interacting with customers is more important than ever.
Through the research questions, the impact of customer-tocustomer interaction on customer's purchase behavior in ecommerce will be approved and give implication on how to make a good management on the customers review and how to maintain customers, which will make great contribution to the management in some degree. ${ }^{[20]}$

\section{REFERENCES}

[1] Anonymous. (2013) China's netizen population hits 591 million. |Society |chinadaily.com.cn

[2] Anonymous. (2013) China's netizen population hits 591 million. |Society |chinadaily.com.cn

[3] Anonymous. (2010) China's e-commerce sites record transactions worth \$332.6 billion in H1. Interfax : China IT Newswire, 2010

[4] Jen-Her Wu, Qi Li \& Kwok Kee Wei. (2016) Alibaba's IT platform and electronic commerce synergy in driving "Singles' Day" Journal of Organizational Computing and Electronic Commerce, Vol.26 (3), pp.193-202 ;

[5] Anonymous.(2015) China invested \$36 billion in Science and technology. Ponenix Technology. http://tech.ifeng.com/a/20151231/41532658_0.shtml

[6] Anonymous. (2015) Which country in the world loves online shopping best? http://fm.m4.cn

[7] Anonymous.(2015) Consumer online rights protected |Society|chinadaily.com.cn

[8] Shopping Online. (2010) http://www.docin.com/p-51628065.html

[9] Li Milong. (2010) Strengths and Weaknesses of Online-shopping http://www.cnki.net/

[10] Zhou Wenting. (2016) China's netizen population hits 591 million. (201.07.17) |Society |chinadaily.com.cn http://www.chinadaily.com.cn/china

[11] Thomas W. Gruen, Talai Osmonbekov \& Andrew J. Czaplewski. (2007) Customer-to-customer exchange: Its MOA antecedents and its impact on value creation and loyalty. Journal of the Academy of Marketing Science December 2007, Volume 35, Issue 4, pp 537-549 SpringerLink http://link.springer.com

[12] Jacob Goldenberg, Barak Libai \& Eitan Muller. (2001) Talk of the Network: A Complex Systems Look at the Underlying Process of Wordof-Mouth http://d.scholar.cnki.net

[13] Mavis T. Adjei, Stephanie M. Noble \& Charles H. Noble. (2010) The influence of $\mathrm{C} 2 \mathrm{C}$ communications in online brand communities on customer purchase behavior, Journal of the Academy of Marketing Science October 2010, Volume 38, Issue 5, pp 634653http://link.springer.com/

[14] Adamu Ibrahim, Sani Bawa, Ismaila S. Abdullahi, Chizoba E. Didigu \& Sani S. Mainasara. (2015). Consumer Confidence Indicators and Economic http://www.doc88.com/p-3137689415307.html

[15] Vala Afshar. (2015). 50 Important Customer Experience Stats for Business Leaders from http://www.huffingtonpost.com/vala-afshar/50important-customer-exp_b_8295772.html

[16] Anum Hussain.(2014). CRM Expert Paul Greenberg Defines Customer Engagement from http://blog.hubspot.com/sales/paul-greenberg-definescustomer-engagement

[17] Ruth C. King, Richard A.M. Schilhavy, Charles Chowa \& Wynne W. Chin. (2016). Do Customers Identify with Our Website? The Effects of Website Identification on Repeat Purchase Intention

[18] Jalal Eddine Bahbouhi \& Najem Moussa. (2017). Prisoner's dilemma game model for e-commerce. Applied Mathematics and Computation, 2017, Vol.292.

[19] Joseph P. Bailey. (1998). Intermediation and Electronic Markets: Aggregation and Pricing in Internet Commerce.

[20] Rakesh Sapna, Khare Arpita.(2008). AN investigation of the consumers predisposition towards enrolling into the retail loyalty cards. 